\title{
Genomic Variants of Bacteriophages Against Salmonella enterica serovar Enteritidis With Potential Application in the Poultry Industry
}

\section{Author(s)}

Robeson J

Retamales $\mathrm{J}^{1}$

Borie $C^{2}$

Laboratorio de Bacteriología Instituto de Biología, Pontificia Universidad Católica de Valparaíso, Valparaíso.

2 Laboratorio de Microbiología, Facultad de Ciencias Veterinarias y Pecuarias, Universidad de Chile, Santiago.

\section{Mail Address}

James Robeson

Instituto de Biología

Pontificia Universidad Católica de Valparaíso

Av. Brasil 2950

Valparaíso, Chile

E-mail: jrobeson@ucv.cl

Keywords

Bacteriophages, Biocontrol, Salmonella Enteritidis.

\section{Acknowledgments}

The authors thank Comisión Nacional de Investigación Científica y Tecnológica de Chile (CONICYT) for the funding granted to one of the authors $(\mathrm{CB})$ thorugh project FONDECYT 1060569, which allowed the development of this research study.

\section{ABSTRACT}

Salmonella enterica serovar Enteritidis (SE) is a prevalent gastrointestinal pathogen worldwide, threatening both animal and human health. In the latter, disease is associated to the consumption of SE-contaminated products from the poultry industry. The control of SE infection is largely based on the use of antibiotics and vaccines, but the use of lytic bacteriophages is re-emerging as an additional strategy for SE control. In fact, a number of recent reports point to the adequacy of bacteriophage as an efficient prophylactic or therapeutic countermeasure to SE infections. However, less attention has been focused on the basic biology of these bacteriophages. Here we report on three bacteriophages (f18, IF1 and EST2) that share a common viral particle morphology but are genomic variants as judged by their EcoRI DNA restriction patterns. Furthermore, they differ in their lytic capability towards SE, being EST2 the most efficient. They show a very narrow host range, efficiently infecting only SE strains. In terms of stability in various suspension media, including distilled water, all three bacteriophages remained viable, without noticeable decay in titer for at least 15 days at $25^{\circ} \mathrm{C}$. These results suggest the suitability of the tested bacteriophages as SE-controlling agents in the poultry industry.

\section{INTRODUCTION}

During the last decades in Chile and worldwide, Salmonella enterica serovar Enteritidis (SE) has emerged as one of the most prevalent pathogens in humans and animals. They cause intestinal disorders that are mainly associated with the consumption of poultry products contaminated with SE (Darwin \& Millar, 1999; Fica et al., 2001; GardPetter, 2001; Seo et al., 2002; De Avila et al., 2003).

The main mechanisms for the control this pathogen are based on the use of antibiotics, vaccines, and probiotics, but the emergence of multi-resistant SE strains requires the adoption of new measures, independent from traditional chemotherapies. This has led to the reemergence of the use of bacteriophages as therapeutic or prophylactic agents as an alternative for the treatment of SE infections (Matsuzaki et al., 2005).

Recent studies indicate the use of lytic bacteriophages as a method to control and detect different bacterial agents, such as Escherichia coli 0157:H7, Mycobacterium, Campylobacter, Listeria, Staphylococcus, and Pseudomonas (Abdul-Hassan et al., 1990; Goodridge et al., 2003; Siquiera et al., 2003; Wagenaar et al., 2005).

The use of bacteriophages for the control of SE has been reported in association with processed fruits (Leverentz et al., 2001) and during Cheddar cheese manufacturing (Modi et al., 2001). Higgins et al. (2005) also studied their effect on broiler carcasses, and found a significant 
reduction of SE infection. Bacteriophages active against SE were successfully used to decrease SE infection levels in broilers (Sklar \& Joerger, 2001; Fiorentin et al., 2005; Toro et al., 2005; Andreatti Filho et al., 2007, Atterbury et al., 2007). In this context, a group of bacteriophages isolated in Chile by Santander \& Robeson (2002), which ability to control SE infection was first studied using Caenorhabditis elegans (Santander \& Robeson, 2004), was recently tested for its capacity to successfully control SE infection in broilers (Borie et al., 2008a) and White Leghorn chickens (Borie et al., 2008b). However, these studies do not detail the genomic architecture of the mentioned bacteriophages or their biological activity in vitro. In fact, only the reports of Santander \& Robeson (2002) and of Fiorentin et al. (2004) establish analysis criteria based on restriction patterns using EcoR 1 and RAPD, respectively. In addition, there is no information as to stability of the viral particles in suspension media for field application.

In this study, we defined the genomic variants of a group of bacteriophages with similar morphology. These variants present different lytic capacity against Enteritidis serovar in in vitro experiments. Bacteriophage suspension conditions for field application were established. It was shown that they remain stable for 15 days.

\section{MATERIALS AND METHODS}

\section{Bacteriophage isolation}

Samples from broiler fecal matter, residual waters of confined animal facilities (horses, ducks, geese, chickens, cattle), municipal sewage waters, and poultry products were collected. Samples were homogenized or diluted in saline solutions, and processed to enrich phages using the method of Santander \& Robeson (2002). To a $100 \mathrm{~mL}$ flash containing LB broth (Miller, 1972) supplemented with rifampicin (Rif, $100 \mu \mathrm{g} / \mathrm{ml}$ ) and nalidixic acid ( $\mathrm{Nal}, 100 \mu \mathrm{g} / \mathrm{ml}$ ) $0.5 \mathrm{ml}$ of an exponentialgrowth culture of a SE strain resistant to both antibiotics and $1 \mathrm{ml}$ of sample were added. The flask was incubated in an orbital shaker at $37^{\circ} \mathrm{C}$ and 250 rpm for 18 to $24 \mathrm{~h}$. Phages were amplified by seeding in order to obtain lysis macroplaques with double agar layer technique using the same SE strain as marker strain (Davis et al., 1980).

\section{Phage purification, amplification, and titering}

The obtained phages were purified by collecting plate forming units (pfu) by understreaking double agar layers. Large-scale bacteriophage amplification was carried out according to the technique detailed in Sambrook et al. (1989). Bacteriophages were titered using dilution in BSG buffer (Gerhardt et al., 1981) and seeding on LB agar plates.

\section{Viral genome analysis}

Phage DNA was isolated according to Kaiser et al. (1989), with modifications (proteinase $K$ instead of pronase). The purified DNA was then digested with EcoR1 restriction enzyme (Gibco, BRL), and fragments were separated by electrophoresis in agarose gel at $0.7 \%$ in TAE buffer, which was stained with ethidium bromide to allow fragment visualization under UV light (Sambrook et al., 1989). The obtained fragments were then compared to the molecular weight standard of DNA fragments of the lambda bacteriophage digested with HindIII (Fermentas, Lithuania).

\section{Electron microscopy of viral particles}

Viral particle morphology was observed by transmission electron microscopy, according to the techniques standardized by Hayat (1989). Phages were fixed in $0.1 \mathrm{M}$ glutaraldehyde in sodium cacodylate buffer ( $\mathrm{pH}$ 7.2). Osmium tetraoxide at $1 \%$ was added to the fixed samples, which were dehydrated in graded series of ethanol. Samples were then negatively stained with uranyl acetate at $4 \%$. Viral particles were observed under electron microscope at $80 \mathrm{kV}$ with $85,000 x$ magnification.

\section{Host range}

Cross-streak seeding was carried out, corroborated by macroplaque essays, to determine the lytic activity presented by selected phages on bacterial strains commonly found in poultry.

\section{"In vitro" phage lytic activity against SE}

An exponential-growth phase SE culture was added to $20 \mathrm{ml} \mathrm{LB}$ broth ( $10 \mathrm{~g}$ triptone; $5 \mathrm{~g} \mathrm{NaCl}, 5 \mathrm{~g}$ yeast extract; $1 \mathrm{~L}$ distilled water). When culture reached an $\mathrm{OD}_{600 \mathrm{~nm}} \approx 0.25$, phages were added at 0.1 multiplicity of infection (MOI), and bacterial reduction was observed every 20 minutes in a spectrophotometer (Spectronic 21D) by measuring $\mathrm{OD}_{600 \mathrm{~nm}}$ at $37^{\circ} \mathrm{C}$. Each bacteriophage was tested in triplicate.

\section{Frequency of phage-resistant SE variants}

An exponential-growth phase SE culture was infected with phages at $1 \mathrm{MOI}$, and incubated in a 
shaker at $37^{\circ} \mathrm{C}$ for $1 \mathrm{~h}$ at $250 \mathrm{rpm}$. The infected culture was then serially diluted in BSG, and plated on LB agar supplemented with Rif and Nal. After incubation for $24 \mathrm{~h}$ at $37^{\circ} \mathrm{C}$, the number of mutants $/ \mathrm{ml}$ was determined.

\section{Phage titer stability}

In order to test bacteriophage stability, dilutions of the three genetically different phages $\left(1 \times 10^{3} \mathrm{pfu} / \mathrm{ml}\right.$.) were incubated at $25^{\circ} \mathrm{C}$, and titer variation in time was determined by seeding in double LB agar plates, using SE as marker strain. The following media tested: BSG buffer (control), BMG (BSG buffer replacing $\mathrm{NaCl}$ by $\left.1 \mathrm{mM} \mathrm{MgSO}_{4}\right)$, distilled water, and peptone water (buffer of the probiotic product for poultry Broilac, Brazil).

\section{RESULTS AND DISCUSSION}

The bacteriophages analyzed in the present study, designated as f18, IF1, and EST2, were selected due their capacity to produce lysis plaques in a SE overlay culture. Bacteriophages from circular lysis plaques with translucent borders were amplified, purified, and examined under electron microscopy.

Viral particle morphology of the three studied bacteriophages (Figure 1) corresponds to B1 morphotype (i.e., are similar to Lambda bacteriophage), with a circular head and tail relatively longer than the head. In addition, they present a basal plaque, although the presence of adherent fibers is not clear. Therefore, the observed morphological characteristics suggest the presence of bacteriophages of the Order Caudovirales, which includes the genera Siphoviridae and Myoviridae. (ICTV, 2007). The examined bacteriophages, due to the morphology of the viral particles, are similar to the bacteriophage $\Phi 10$ described by Atterbury et al. (2007).

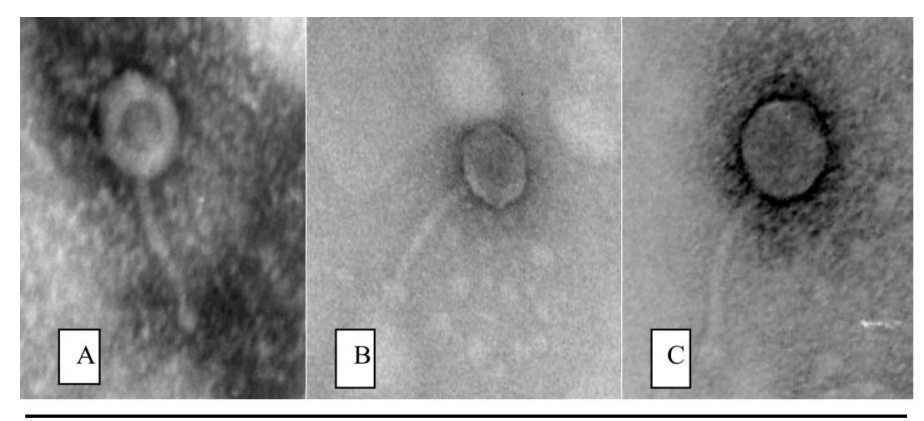

Figure 1 - Electron microscopy of the phages active against $\mathrm{SE}$, 85.000x: A. f18; B. IF1; C. EST2.
The examination of the genome of the bacteriophages determined that their molecular mass was similar do the lambda bacteriophage DNA (49 Kpb) and that they present a characteristic pattern when treated with the enzyme EcoR1. The susceptibility of the genomes to EcoR1 and DNase (data not shown) indicate that they correspond to a bicatenary DNA. These results of this analysis are shown in Figure 2, A and $B$, and indicate that this is a homogenous phage group with some genomic variants. This is consistent with the selection of bacteriophages using a single SE strain. However, it is not clear if these bacteriophages, under the perspective of genomic architecture, are different from those reported by Fiorentin et al. (2004), who used RAPD for viral DNA analysis. Further data on the genomic sequence of these different bacteriophages are required to establish possible homologies. This information is essential to design genetic modification strategies aiming at improving the lytic capacity of SE-controlling bacteriophages.

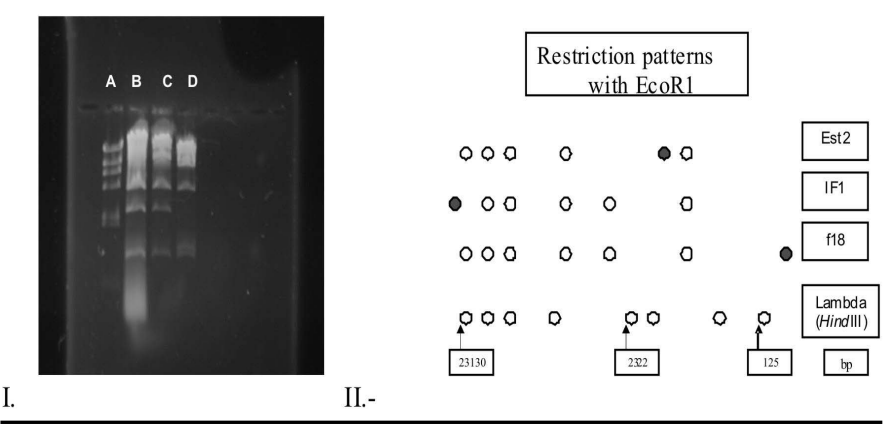

Figure 2 - I. Restriction patterns with the enzyme EcoR1. A. Marker ë HindIII; B. phage f18; C. phage IF1; D. phage EST2. II. Diagram of the restriction patterns with the enzyme EcoR1 (differences in dark dots).

The host range of these phage genomic variants may explain the specificity of these biological control agents (Table 1). The lytic activity is similar among the studied phages and it affects only the Enteritidis serovar of the genus Salmonella. The remaining tested strains, which are usually present in poultry, are resistant to the action of phages f18, IF1, and EST2. It must be noted that the studied bacteriophages do not affect bacterial strains present in the intestinal flora of broilers, and therefore, would not result in dysbiosis, which may be caused by the use of antibiotics.

The main difference among the three studied phage genomic variants is the time required to promote $\mathrm{SE}$ lysis in vitro, as demonstrated by the decrease in $\mathrm{OD}_{(600}$ $n m$.$) . These results are shown in Figure 3. The phage$ genomic variants called EST2 and $f 18$ were more efficient to decrease $O D_{(600 \mathrm{~nm} .)}$ from 0,65 (which was 
used as control, corresponding to SE growth in the absence of bacteriophages) to 0,05 at the end of the incubation period. Phage EST2 reached these results 60 min post-infection, whereas f18 required the entire incubation period of $3 \mathrm{~h}$. The genomic variant IF1 only decreased $\mathrm{OD}_{(600 \mathrm{~nm})}$ to 0.02 , as compared to the control. Therefore, the phage genomic variants EST2 and f18 may be good biological agents for SE control. The results obtained in the present study are more favorable as compared to those of Attebury et al. (2007), who reported a less intense lytic activity of the bacteriophages they tested.

\begin{tabular}{lccc}
\hline \multicolumn{2}{l}{ Table 1 - Host range of the studied bacteriophages. } \\
\cline { 2 - 4 } Bacterial strains & $\mathbf{4}$ & Bacteriophages \\
\hline SE ATCC 13076 & +++ & +++ & +++ \\
SE PT4 & +++ & +++ & +++ \\
SE P7 & +++ & +++ & +++ \\
SE 864 (isolated from broilers) & + & + & + \\
S. Heilderberg 750 & + & + & + \\
S. Heilderberg 1210 & + & + & + \\
S. Heilderberg 637 & + & + & + \\
S. Heilderberg 660 & + & + & + \\
S. Agona x65 & - & - & - \\
S. Cholerasuis 3246 & - & - & - \\
S. Typhimurium ATCC 3179 & - & - & - \\
Escherichia coli C & - & - & - \\
E. coli 8B (isolated from broilers) & - & - & - \\
E. coli 5C (isolated from broilers) & - & - & - \\
Enterobacter sp. & - & - & - \\
Citrobacter sp. & - & - & - \\
Proteus vulgaris & - & - & - \\
Erwinia carotovora & - & - & - \\
\hline
\end{tabular}

(+++: no bacterial growth after exposure to the bacteriophage; ++: reduced bacterial growth after exposure to the bacteriophage; + mild effect on bacterial growth only zone of exposure to the bacteriophage; -: no effect on bacterial growth after exposure to the bacteriophage). The bacterial strains tested belong to the collections of the Bacteriology laboratory of Instituto de Biología, Pontificia Universidad Católica de Valparaíso, and of the Microbiology laboratory of Facultad de Ciencias Veterinarias y Pecuarias, Universidad de Chile.

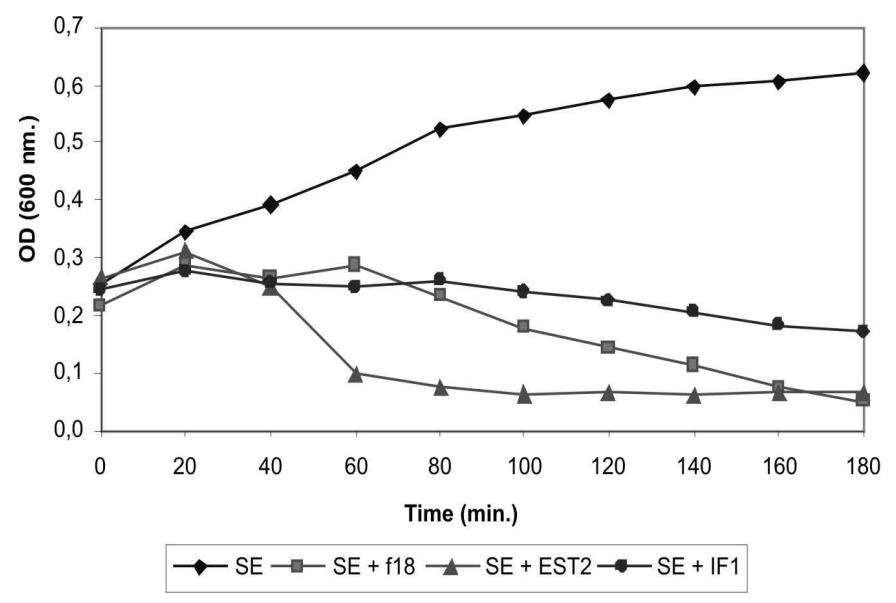

Figure $\mathbf{3}$ - In vitro SE reduction caused by bacteriophages.
A relevant aspect in the context of the application of bacteriophages as agents to control bacterial infections is the selection of resistant mutant bacteria, which could be a negative aspect of the use of such biocontrol agents. In this sense, it must be mentioned that phage-resistant SE mutant strains were detected at a level of $10^{-4}$ mutants* ml-1 (Figure 4). Santander \& Robeson (2007) in SE, and Park et al. (2000) in Pseudomonas plecoglossicida, found that this resistance to bacteriophages is due to a change in the bacterium surface, specifically to the loss of an important bacterial LPS site that is used by the phage to recognize and to adhere to the bacterium: the $\mathrm{O}$ Polysaccharide (O-PS). However, this O-PS loss also results in the loss of the bacterial virulence, infective capacity, and capacity to kill the nematode Caenorhbditis elegans (Santander \& Robeson, 2007). Therefore, in the case of the bacteriophages tested in the present study, the emergence of resistant SE mutants does not hinder the use of those biocontrol agents. In addition, these bacteriophage-resistant SE mutants could be used as seeds for the selection of new bacteriophages against SE.

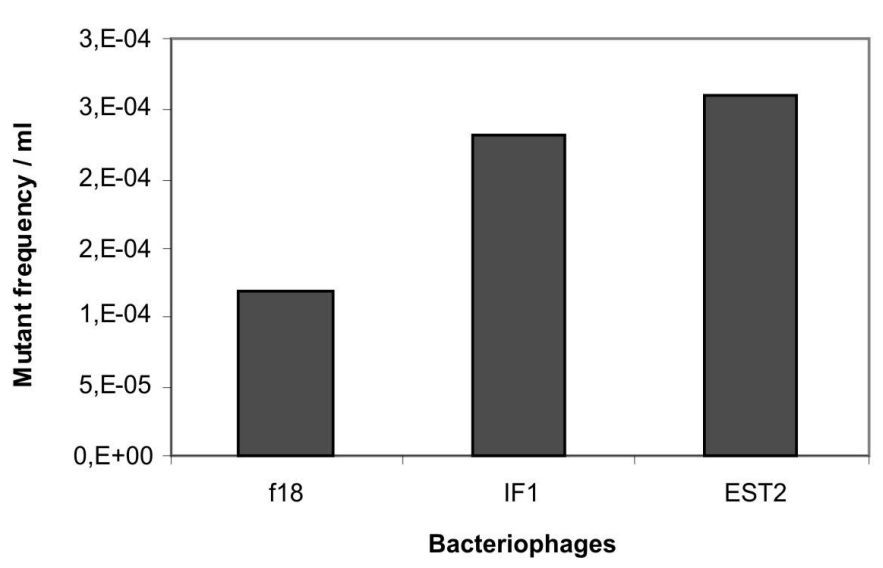

Figure 4 - Frequency of bacteriophage-resistant SE mutants.

Suspension media and phage application are essential to ensure the efficacy of these agents in the control of SE in poultry houses, and therefore titer stability in different suspension media must be determined before its massive and industrial prophylactic application. In order to ensure the success of bacteriophages as SE-control agents in poultry production, different suspension media were tested in vitro. The results indicated that the studied media presented excellent conditions to maintain stable phage titers (Figure 5). However, the use of magnesium- 

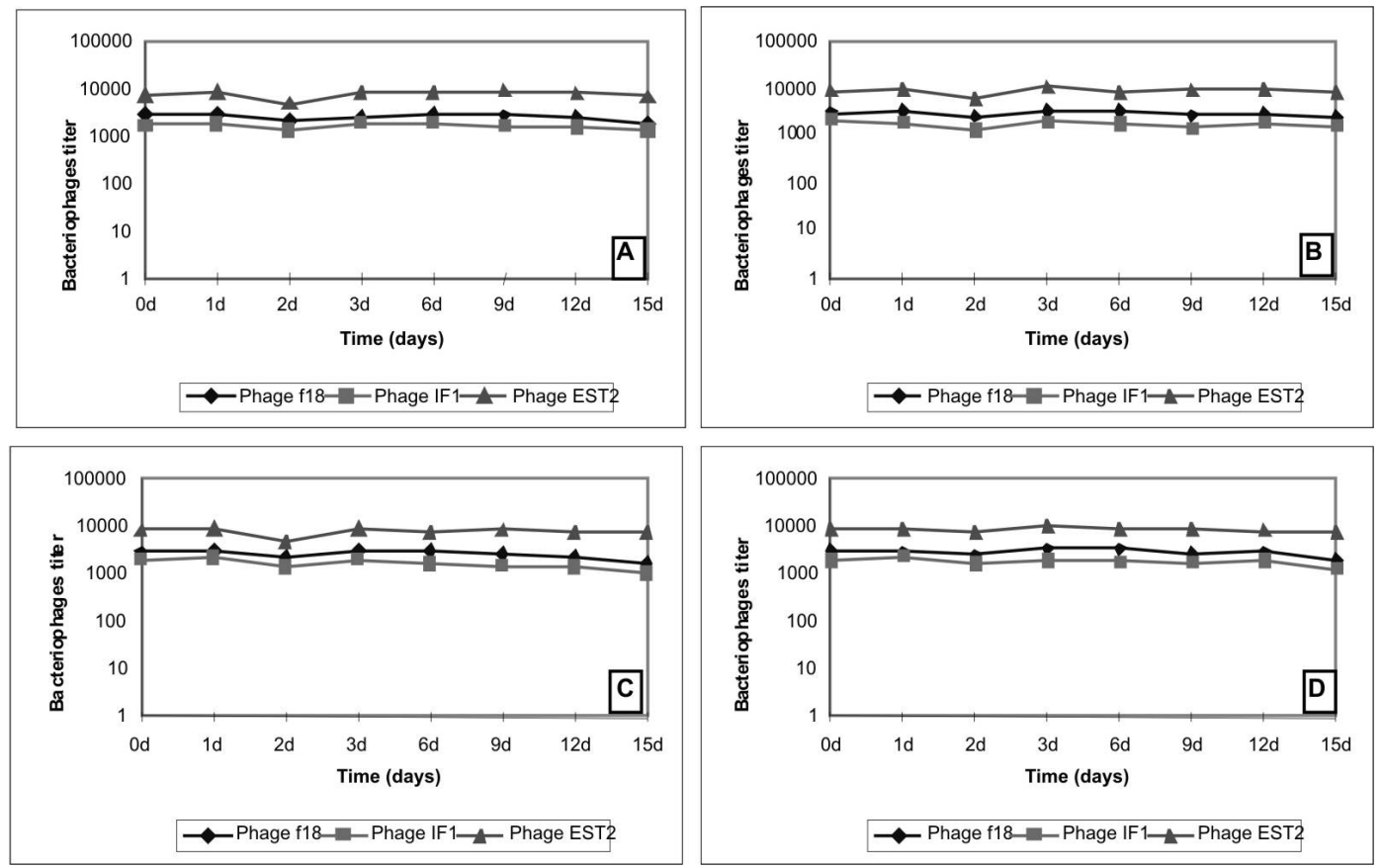

Figure 5 - Titer stability of the studied bacteriophages in different suspension media. A. BSG buffer (control); B. BMG buffer; C. Probiotic buffer; D. Distilled water (pH 7.0)

supplemented phosphate buffer is recommended over BSG buffer, which contains $\mathrm{NaCl}$ and may irritate birds' eyes if the phage solution is sprayed. Distilled water may cause titer variation, and therefore, lytic activity variation if $\mathrm{pH}$ or dissolved salts are not duly controlled. Also, under the context of prophylaxis, the studied bacteriophages maintained their titers in suspension media containing probiotic bacterial strains, opening the possibility of developing phage-enriched probiotic products for the control of SE in poultry production.

\section{CONCLUSION}

Genomic variants of bacteriophages belonging to the same morphotype were determined. These variants had different lytic activity against SE, and variants EST2 and f18 could potentially be used as agents for the control of SE infections. In addition, the use of phosphate buffer supplemented with $1 \mathrm{mM} \mathrm{Mg}^{++}$and $0.01 \%$ gelatin for the field application of bacteriophages is recommended.

\section{REFERENCES}

Abdul-Hassan H, El-Tahan S, Massoud B, Gomaa R. Bacteriophage therapy of pseudomonas burn wound sepsis. Annals of the Mediterraneans Burns Club 1990; 3:262-264.

Andreatti Filho RL, Higgins JP, Higgins SE, Gaona G, Wolfenden
AD, Tellez G, Hargis BM. Ability of bacteriophages isolated from different sources to reduce Salmonella enterica serovar Enteritidis in vitro and in vivo. Poultry Science 2007; 86(9):1904-1909.

Atterbury RJ, Van Bergen MAP, Ortiz F, Lovell MA, Harris JA, De Boer A, Wagenaar JA, Allen VM, Barrow PA. Bacteriophage therapy to reduce Salmonella colonization of broiler chickens. Applied and Environmental Microbiology 2007; 73 (14): 4543-4549.

Avila L de, Nascimento V do, Canal C, Salle H, Moraes H. Effect of acidified drinking water on the recover of Salmonella enteritidis from broilers crops. Brazilian Journal of Poultry Science 2003; 5(3):183-188.

Borie C, Albala I, Sánchez P, Sánchez ML, Ramírez S, Navarro C, Morales MA, Retamales J, Robeson J. Bacteriophage treatment reduce Salmonella colonization of infected chickens. Avian Diseases 2008b; 52:64-67.

Borie C, Zurita P, Sánchez ML, Rojas V, Santander J, Robeson J. Prevención de la infección por Salmonella enteritidis en pollos mediante un bacteriófago. Archivos de Medicina Veterinaria. En prensa $2008^{a}$

Darwin H, Millar V. Molecular basis of the interaction of Salmonella with the intestinal mucosa. Clinical Microbiology 1999; 12(3):405428.

Davis R, Botstein D, Roth J. A manual for genetic engineering: advanced bacterial genetics. 2nd ed. New York (NY): Cold Spring Harbour Laboratory; 1980.

Fica A, Alexandre M, Prat S, Fernandez A, Fernanadez J, Heitmann, I. Cambios epidemiológicos de las salmonelosis en Chile, desde 
Salmonella typhi a Salmonella enteritidis. Revista Chilena de Infectología 2001; 18(2):85-93.

Fiorentin L, Viera ND, Barioni Júnior W. Oral treatment with bacteriophages reduces the concentration of Salmoenlla enteritidis PT4 in caecal contents of broliers. Avian Pathology 2005; 34(3): 258-263.

Fiorentin L, Viera ND, Barioni Júnior W, Barros S. In vitro characterization and in vivo properties of Salmonella lytic bacteriophages isolated from free-range layers. Brazilian Journal of Poultry Science 2004; 6(2):121-128.

Gard-Petter, J. The chicken, the egg and Salmonella enteritidis. Environmental Microbiology 2001; 3(7):421-430.

Gerhardt P, Murray R, Costilow R, Nester E, Wood W, Krieg N, Phillips $G$. Manual of methods for general bacteriology. 2nd ed. Washington(DC): American Society for Microbiology; 1981.

Goodridge L, Gallaccio A, Griffiths M. Morphological, host range, and genetic characterization of two coliphages. Applied and Environmental Microbiology 2003; 69(9):5364-5371.

Hayat M. Principles and techniques of electron microscopy biological applications. 3nd ed. Boca Raton (FL): CRC Press; 1989.

Higgins J, Higgins S, Guenther K, Huff W, Donoghue A, Donoghue $D$, Hargis $B M$. Use of a specific bacteriophages treatment to reduce Salmonella in poultry products. Poultry Science 2005; 84:11411145.

Leverentz B, Conwai W, Alavidze Z, Jansiewicz W, Fuchs Y, Camp M, Chighladze $E$, Sulakvelidze A. Examination of bacteriophages as a biocontrol method for Salmonella on fresh-cut fruit: A model study. Journal of Food Protection 2001; 64(8):1116-1121.

Matsuzaki S, Rashel M, Uchiama J, Sakurai S, Ujihara T, Kuroda M, Ikeuchi M, Tani T, Fujieda M, Wakiguchi H, Imai S. Bacteriophages therapy: a revitalized therapy against bacterial infectious diseases. Journal of Infection and Chemotherapy 2005; 11:211-219.

Miller J. Experiments in molecular genetics. New York (NY): Cold Spring Harbor Laboratory; 1972.

Modi R, Hirvi Y, Hill A, Griffiths M. Effect of phage on survival of Salmonella enteritidis drying manufacture and storage of cheese made from raw and pasteurized milk. Journal of Food Protection 2001; 64(7):927-933.

Park S, Shimamura I, Fukunaga M, Mori K, Nakai T. Isolation of bacteriophages specific to a fish pathogen, Pseudomonas plecoglossicida, as a candidate for disease control. Applied and Environmental Microbiology 2000; 66(4):1416-1422.

Sambrodk J, Fritsch E, Maniatis T. Molecular cloning: a laboratory manual. 2nd ed. New York (NY): Cold Spring Harbor; 1989.

Santander J, Robeson J. Aislamiento y caracterización de bacteriófagos líticos contra Salmonella enteritidis y su ensayo sobre Salmonella pullorum. Acta Microbiológica 2002; 8(1):17-22.
Santander J, Robeson J. Bacteriophages prophylaxis against Salmonella enteritidis and Salmonella pullorum sing Caenorhabditis elegans as an assay system. Electronic Journal of biotechnology 2004; 7(2):206-209.

Santander J, Robeson J. Phage-resistance of Salmonella enterica serovar Enteritidis and pathogenesis in Caenorhabditis elegans is mediated by the lipopolysaccharide. Electronic Journal of Biotechnology 2007; 10(4):627-632.

Seo K, Holt P, Brackett R, Gast R, Stone H. Mucosal humoral immunity to experimental Salmonella enteritidis infection in the chicken crop. Avian Diseases 2002; 4(6):1015-1020.

Siqueira R, Dodd C, Rees C. Phage amplification assai as rapid method for Salmonella detection. Brazilian Journal of Microbiology 2003; 34:118-120.

Sklar I, Joerger R. Attemps to utilize bacteriophages to combat Salmonella enterica serovar Enteritidis infection in chickens. Journal of Food Safety 2001; 21:15-29.

Toro H, Price B, Mckee S, Hoerr F, Krehling J, Perdue M, Bauermeister $\mathrm{L}$. Use of bacteriophages in combination with competitive exclusion to reduce Salmonella from infected chickens. Avian Diseases 2005; 49:118-124.

Wagenaar J, Van Bergen M, Meller M, Wassenaar T, Carton R. Phage therapy reduces Campylobacter jejuni colonization in broilers. Veterinary Microbiology 2005; 109:275-283. 